\title{
The Political Economy of the Academic Library
}

\section{Dennis P. Carrigan}

Because there are economic and political aspects to the operation of the academic library and its parent university, it is appropriate to refer to the "political economy of the academic library," and fruitful to apply the political economy paradigm in an effort to understand the library fully. Three significant aspects of the political economy of the academic library are discussed, as is the anarchic nature of the university, and implications for the academic library.

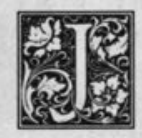

ust as where a person stands exerts a powerful influence on what is seen, so the place a person looks for the answer to a question delimits the set of potential choices.

The foregoing is obvious. It is equally obvious that every individual, group, or organization exists and functions within an environment with which it must relate and by which it is influenced. Similarly, a question about how an organization works may yield one answer if the analysis is limited to the internal workings of the organization and quite another if it is limited to its environment.

When setting out to understand an organization fully, one must go beyond its internal workings and seek an understanding of any parent institution, the relationship between the two, and the constraints that the parent imposes upon the smaller organization. The American university is an excellent case in point. To understand the American university and its evolution over the past century and a quarter one must have an understanding of the greater society and the profound changes it has endured.

In his study of the emergence of the American university, Laurence Veysey writes, "The American University of 1900 was all but unrecognizable in comparison with the college of 1860 ." Veysey contends that the transformation was the result of several forces, of which the three most important were "Europhilic discontent, available national wealth, and immediate alarm over declining college influence." All were the result of changes that occurred not within the university, but rather within the broader American society. ${ }^{1}$

The rapid development of research universities that occurred between the late 1800 s and 1920 s was also vitally related to changes in the broader society. In this regard, Roger Geiger cites three issues: the ability to acquire social resources; the conversion of some resources to create a research capability; and most importantly, the securing of an "extramural supply of resources earmarked for research, " an undertaking in which the large generalpurpose foundations had become increasingly important, especially following World War I.

Geiger makes it clear that the research universities could not have succeeded if society had not produced the wealth and the frame of mind essential for their support. ${ }^{2}$ Economic expansion was especially

Dennis P. Carrigan is Assistant Dean at the College of Library and Information Science, University of Kentucky, Lexington, Kentucky 40506-0039. 
robust from the last years of the nineteenth century through World War I. During that period higher education qualified as a growth industry in two respects: Directly, because of surging enrollment; and indirectly as a "beneficiary of the burgeoning national economy." These factors enabled research universities' incomes to grow by a factor of five between 1900 and $1920 .^{3}$

Growth in higher education during the first part of the twentieth century was not limited to research universities, as a result of the formation and development of a "culture of aspiration," to use David Levine's felicitous phrase. ${ }^{4}$ Further, the growth of American higher education was stimulated by

a remarkable confluence of economic, social, and intellectual developments that had first appeared in the Progressive Era and gathered momentum after World War I. . . Expansion served the needs of the rapidly growing professional and service-oriented sectors for training and legitimacy. ... The curriculum became inextricably tied to the nation's economic structure, particularly its burgeoning white-collar, middle-class sector. ${ }^{5}$

Institutions of higher learning were not driving changes in American society. Quite the reverse was true, and it is only by understanding the broader society that we can appreciate the dramatic changes that occurred in higher education.

Clark Kerr writes that " $[t]$ he university does not fully control the direction of its own development" and concludes that "it seldom has. ${ }^{\prime 6}$ In his classic study, The Uses of the University, Kerr states that "the truly major changes have been initiated from the outside" and the university's "directions have not been set as much by the university's visions of its destiny as by the external environment. . . . The industrial, democratic, and scientific revolutions," Kerr observes, "have gradually moved in on the universities and changed them almost beyond recognition. ${ }^{\prime 7}$

The university of today bears little resemblance to its historical antecedent, but it does bear a strong resemblance to its host culture. Harvard president Derek Bok writes that the contemporary American university has grown "out of deep- rooted values in the native culture: a distrust of government and an abiding faith in competition. ${ }^{18}$ As Abraham Flexner wrote more than fifty years ago, this is because the university, "like all other human institutions," is "an expression of an age."'9

\section{THE ACADEMIC LIBRARY AND THE POLITICAL ECONOMY PARADIGM}

The academic library, like its parent institution, is embedded within the fabric of something larger. To understand the academic library, one may turn to such standard texts as those by Guy Lyle on college library administration, or Rutherford Rogers and David Weber on university library administration. ${ }^{10}$ Alternatively, one may focus on the library as an organization, as an economic system, or as a life system. ${ }^{11}$ Another fruitful, important approach is the exploration of the academic library's link with and the nature of its parent university, in short, what I refer to as the political economy of the academic library.

The term political economy has a rich history, although it has fallen into disuse. Edwin Seligman pointed out more than fifty years ago that "the line of demarcation between the subject matter of economics and that of other social scientific disciplines is very shadowy. ${ }^{\prime \prime 2}$ Moreover, political science and economics, now separate disciplines, grew out of a common concern for the social distribution of things of value.

\section{"The study of politics is the study of influence and the influential ... those who get the most of what there is to get."}

Economics today is defined as "the study of the allocation of scarce resources among unlimited and competing uses." ${ }^{13}$ In his classic work suggestively entitled Politics: Who Gets What, When, How?, Harold Lasswell asserts that "the study of politics is the study of influence and the influen- 
tial. . those who get the most of what there is to get." 14

Few would disagree with the statement that there is a vital economic dimension to the operation of the academic library and its parent university. Moreover, I anticipate general agreement with the statement that the academic library exists and functions within a political context. But it is imperative that political be understood in a value-free sense. Too often the term is used pejoratively to describe "a milieu hospitable to scheming and manipulation," or, to use Emerson's term, "cunning. ${ }^{\prime 15}$ That is not the sense in which the term is used here. I refer to that which is "predominantly oriented toward the authoritative allocation" of valued things in a society or a group, to include, of course, a university. David Easton defines authoritative allocations as those that "distribute valued things among persons or groups" by requiring the surrender of, obstructing the attainment of, or providing access to the valued things. An allocation is authoritative "when the persons oriented to it consider that they are bound by it." Thus, when we use the expression political system of groups, we understand it to include the political system that is a vital part of the university and the library. ${ }^{16}$

It is the intrusive presence of an economic dimension and the existence of a political context within which the university and the library exist and function that make the application of the political economy paradigm useful in our efforts to understand the library fully. The political economy paradigm, according to Peter Jackson, "focuses attention upon resource allocations and decision making within an organisation, irrespective of the organisation type." For our purposes, the relevant organization is not the library, but rather its parent university. "Focus upon the internal processes of decision making and resource allocation [within the university] brings together political and economic dimensions of the same problems," Jackson continues. These problems concern bargaining over competing goals, the arrangement of goals in a hierarchy, de jure and de facto bargaining and decision-making systems, and the al- location of scarce resources among competing claims. It is this inevitable bringingtogether of the economic and the political that renders the term political economy so felicitous. ${ }^{17}$

The sociologist Mayer Zald argues that:

the political economy approach requires an analysis that focuses on the interaction of values and goals of power and control groups with (1) the external supply of money and other incentives and the demand for services of clients and funders and (2) the internal allocation of men, money, and facilities to accomplish tasks.

Zald makes two especially important points when considering the political economy of the academic library:

Economies, whether within nation-states or organizations, require a division of labor related to the state of the practical arts (technology). Organizational economies, however, unlike those of societies, do not proceed by market processes; instead, the mechanisms for allocating men, facilities, and money are carried out either by inter-group bargaining or by hierarchical assignments. ${ }^{18}$

Moreover, it is important to understand that the academic library has an "organizational economy," even if it levies no charge for its services. "An organization's economy," Gary Wamsley and Mayer Zald write, "is its system for producing the 'output' of the organization, it is the combination of men, money, machines, and facilities to produce 'desired' output. ${ }^{\prime 19}$

"The revolution in information technology has created ... totally new capacities for generating, storing, and providing access to scholarly information-capacities which no longer represent or require links to physical objects in stationary collections."

Zald's first observation pertaining to a technology-determined division of labor reminds us that for centuries technology has ordained the academic library model that continues to exist today. Neverthe- 
less, as Patricia Battin writes, "The revolution in information technology has created...t totally new capacities for generating, storing, and providing access to scholarly information-capacities which no longer represent or require links to physical objects in stationary collections. ${ }^{\prime 20}$ And, it should be obvious, these are capacities that contain the potential for profound change in the political economy of the academic library. Yet as profound as the possibility is, the second of Zald's observations, that "the mechanisms for allocating men, facilities, and money are carried out either by inter-group bargaining or by hierarchical assignments, ${ }^{\prime 21}$ is of greater interest to us.

\section{THE LIBRARY AS AN EXTERNALLY CONSTRAINED ORGANIZATION}

It is far more likely that one would overestimate, rather than underestimate, the importance of hierarchical assignments in considering the allocation of university resources for the library. Conversely, it is more likely that one would underestimate the importance of intergroup bargaining. Further, we must appreciate fully Zald's point that although the degree varies among organizations and circumstances, nevertheless organizations tend to be dependent upon the external environment for the resources they require. Thus, as Pfeffer and Salancik have written, an organization is "externally constrained," and faces an "environment of competing, frequently conflicting, demands." 22

Moreover, it is because of this competition for resources that "establishing a coalition large enough to ensure survival is an organization's most critical activity. ${ }^{\prime 23}$ Although their external environments differ, both the library and its parent university are "externally constrained" organizations. However, the degree of external constraint is far greater in the case of the library.

Beyond establishing a coalition, however, an organization survives by entering into exchanges with relevant segments of its environment. The organization provides something of value-goods or services-in return for which the recipients provide the support the organization requires. It is this process of exchange that gives rise to the supporting coalition. The majority of exchanges are characterized by their bilateral nature, in which goods or services are provided to a customer who, in turn, provides support in the form of money. Examples abound, from the barber shop to the automobile dealer. The hallmark of such exchanges is the close link between the level of customer satisfaction and the level of support provided.

\section{THE POLITICAL ECONOMY OF THE ACADEMIC LIBRARY: THREE CONSEQUENCES}

No simple exchange exists between the academic library and its "customers," and the absence of a direct exchange relationship is one of the most significant aspects of the political economy of the academic library. In the academic library, the exchange is at best trilateral. Patrons who consume library services do not control or provide the resources upon which the library depends. On the other hand, the administration, which does control the resources, is not a major consumer of library services.

Patron satisfaction with library services may work to the library's advantage when the administration allocates resources. However, at times of resource inadequacy-the very times the library most needs the help of its supporting coalition-it is likely to have the least support. This is because, under these circumstances, the library is competing in a zerosum game: ${ }^{24}$ Money for the library means less money for the university's other constituencies, and at such times even those members of the university community who are normally members of the library's supporting coalition can be expected to place their own, more narrow, interests first.

The zero-sum nature of the competition for resources at times of revenue shortage is aggravated by a third significant aspect of the political economy of the academic library: in the typical university, power is highly dispersed, making it difficult to achieve significant changes in the funding pattern. Power, like political, is a term we may prefer to think of as irrelevant to the 
academy, yet such a thought is selfdeceptive. Power permeates the academy, as it does the relations among all social units and "the behaviors of one or more units . . . depend in some circumstances on the behavior of other units." 25

\section{UNIVERSITY AND ANARCHY}

In his study of the modern "multiversity," Clark Kerr deals extensively with the related issues of governance and power. "What I meant by the word [multiversity]," Kerr writes in the postscript to the 1982 edition, "was that the modern university was a pluralistic institution-pluralistic in a number of senses: in having several purposes, not one; in having several centers of power, not one; [and] in serving several clienteles, not one." Kerr suggests that although the modern university is "devoted to equality of opportunity, it is itself a class society. A community ... should have common interests; in the multiversity, they are quite varied, even conflicting. ${ }^{\prime 26}$

Seeking a way to describe governance in the modern university, Kerr turns to the city for analogy: "It is . . . a system of government like the city, or a city state. . . . It may be inconsistent, but it must be governed-not as the guild it once was, but as a complex entity with greatly fractionalized power. . . . There is a 'kind of lawlessness' in any large university with many separate sources of initiative and power;" "Kerr continues, "and the task is to keep this lawlessness within reasonable bounds." Faculty are at the same time both major competitors for that power and the principal assurance that it will remain fractionalized. Kerr goes on to quote Robert M. Hutchins' assertion that "the faculty really 'prefer anarchy to any form of government.'

Anarchy and sharply constrained power emerge as major themes in Michael Cohen and James March's study of the American college and university president. The American college and university, they write, belong "to a class of organizations that can be called organized anarchies." They view "college [and university] presidents as generally more powerful than others in the college [or university] but as having less power than casual observers or participants frequently believe they do, or than they often expect to have on entering office. .... Except for a very few cases," Cohen and March observe, "presidents do not appear to dominate directly the decision making in their institutions. They face a poorly understood and rather tightly constrained managerial world. . . . Their ability to control decision outcomes is often less than expected by those around them and by themselves." ${ }^{\prime 28}$

Yet, if the president has less power than might appear to be the case, where does power reside? The answer seems to be: Everywhere-and therefore nowhere. "Both formal authority and informal influence are widely diffused in a university, as compared with other types of formal organizations," Frederick Balderston writes. Moreover, "the individuals in a university retain very significant autonomy. This gives them many vetoes over the official intentions of authority. ${ }^{\prime 29}$ From the perspective of fifteen years as president of Harvard, Derek Bok observes that "universities are anarchic by nature and flourish by giving professors free reign." ${ }^{30}$

Clark Kerr writes that, especially with regard to research universities, "the faculties are substantially in control." Kerr comments on the major consequence of nearly twenty years of evolution in the governance of the university, during which decision making has become ever more diffused: "It is ironic that participatory democracy ... has meant . . . more veto groups, less action, more commitment to the status quo-the status quo is the only solution that cannot be vetoed. ${ }^{\prime 31}$

\section{POLITICAL ECONOMY, ANARCHY, AND IMPLICATIONS FOR THE LIBRARY}

For the library, the most important implications of the structure and functioning of the university are obvious. On the one hand, it is difficult to secure increases in the percentage of the university's operating budget that is allocated to the library. 


\section{"During times of financial hardship, the library budget is especially vul- nerable."}

On the other, during times of financial hardship, the library budget is especially vulnerable. "When [university] budgets are tightened," Balderston points out,

the library's subsidy budget is likely to come under attack for various reasons. First, the library is a supporting activity, not a direct contributor to goal attainment. (It stands in weak complementation to academic goals.) Second, circulation of books is an observable work-load factor, but the penalty to scholarship from a cutback in numbers of new titles is hard to prove (and is tied to the more exotic research outputs, which are not likely to find as much favor with legislative or alumni fundors as does the accommodation of students). Finally, the yardstick of collection quality in each field is a moving target, consisting ideally of the inclusion of everything old and everything new. Because no library can meet this ideal, the issue is how far to compromise. When put in these terms, the subsidy investment in the library collection is very difficult to objectify. ${ }^{32}$

Balderston's conclusion-that the library's budget is vulnerable-is correct, but I wonder if his reasons are. They strike me as too antiseptic, too dispassionate, too far removed from the way the world, including the university, works. $\mathrm{He}$ is substantially closer to the mark, it seems to me, when, concerning the reality within which a budget reduction must be implemented, he writes: "There is . . . an internal distribution of power and influence in the academic leadership, [and e]ven during the early stages of [a budget reduction], some units may demand par- tial or full exemption from the cuts."

Before members of the "academic leadership" would "demand partial or full exemption" from budget cuts, they would have to be quite certain of their power and influence within the university. Is it likely that a library director would be in a position to make such a demand? Almost certainly, there have been directors who enjoyed such a position. There may be some today, but there will never be many. The position they occupy simply does not carry with it such power and influence. In this regard, Patricia Battin makes an observation that is no less accurate for being painful:

The most striking feature of traditional academic organizations, and the one I believe is most misunderstood and ignored by our academic colleagues, is the virtual isolation of the library in the organization. Despite the rhetoric about it being the heart of the university, the library and librarians have been for years isolated from the policy councils of most institutions. ${ }^{34}$

Whether library directors' academic colleagues misunderstand and ignore "the virtual isolation of the library" in the university, or whether, in fact, they understand fully the relative postition of the library and find that position to be both appropriate and nonthreatening, is a matter worthy of debate. What is beyond debate, however, is Balderston's observation that "librarians administer large, hierarchical organizations and large, institutionally subsidized budgets. Because of the competing and often contradictory demands for relations with insistent outside users, librarians are often experts in political accommodation. ${ }^{\prime \prime 3}$ Or, if they are not experts, they need to be; for such is the reality of the political economy of the academic library.

\section{REFERENCES AND NOTES}

1. Laurence R. Veysey, The Emergence of the American University (Chicago: Univ. of Chicago Pr., 1965), p.2.

2. Roger L. Geiger, To Advance Knowledge: The Growth of American Research Universities, 1900-1940 (New York: Oxford Univ. Pr., 1986), p.vi-vii.

3. Ibid., p.39-40.

4. David O. Levine, The American College and the Culture of Aspiration, 1915-1940 (Ithaca, N.Y.: Cornell Univ. Pr., 1986), p.14. 
5. Ibid., p.18-19.

6. Clark Kerr, The Uses of the University (Cambridge: Harvard Univ. Pr., 1964), p.107.

7. Ibid., p.105; p.122; p.98.

8. Derek Bok, Higher Learning (Cambridge: Harvard Univ. Pr., 1986), p.10.

9. Abraham Flexner, Universities: American, English, German 2d ed. (New York: Teachers College Pr., 1967), p.19.

10. Guy R. Lyle, The Administration of the College Library, 4th ed. (New York: H. W. Wilson, 1974); Rutherford D. Rogers and David C. Weber, University Library Administration (New York: H. W. Wilson, 1971).

11. David W. Lewis, "An Organizational Paradigm for Effective Academic Libraries," College \& Research Libraries 47:337-53 (July 1986); W. Boyd Rayward, "Libraries as Organizations," College \& Research Libraries 30:312-26 (July 1969); Maurice P. Marchant, "University Libraries as Economic Systems," College \& Research Libraries 36:449-57 (Nov. 1975); Timothy C. Weiskel, "Libraries as Life-Systems: Information, Entropy, and Coevolution on Campus," College \& Research Libraries 47:545-63 (Nov. 1986).

12. Edwin R. A. Seligman, "Economics," in Encyclopaedia of the Social Sciences, ed. Edwin R. A. Seligman and Alvin Johnson (New York: Macmillan, 1931), p.344.

13. Albert Rees, "Economics," in International Encyclopedia of the Social Sciences, ed. David L. Sills (New York: Macmillan and the Free Pr., 1968), p.472.

14. Harold D. Lasswell, Politics: Who Gets What, When, How? (New York: McGraw-Hill, 1936), p.3.

15. Lindsay Rogers, "Politics," in Encyclopaedia of the Social Sciences, p.225; Ralph Waldo Emerson "Politics," in Essays \& Lectures, ed. Joel Porte (New York: Library of America, 1983), p.563.

16. David Easton, A Framework for Political Analysis (Englewood Cliffs, N.J.: Prentice-Hall, 1965), p.50.

17. P. M. Jackson, The Political Economy of Bureaucracy (Totowa, N.J.: Barnes \& Noble, 1983), p.73-74.

18. Mayer N. Zald, Organizational Change: The Political Economy of the YMCA (Chicago: Univ. of Chicago Pr., 1970), p.18-19.

19. Gary L. Wamsley and Mayer N. Zald, The Political Economy of Public Organizations (Lexington, Mass.: Heath, 1973), p.19.

20. Patricia Battin, "The Library: Center of the Restructured University," in Colleges Enter the Information Society, ed. Russell Edgerton (Washington: American Association for Higher Education, 1983). p.26.

21. Zald, Organizational Change, p.19.

22. Jeffrey Pfeffer and Gerald Salancik, The External Control of Organizations (New York: Harper, 1978), p.xi-xii.

23. Ibid., p.24-25.

24. For a brief discussion of the zero-sum game, see Edwin Mansfield, Microeconomics: Theory and Applications (New York: Norton, 1970), p.313-14; Fred Hirsch, Social Limits to Growth (Cambridge: Harvard Univ. Pr., 1976), p.52.

25. Robert A. Dahl, "Power," in International Encyclopedia of the Social Sciences, p.407.

26. Clark Kerr, The Uses of the University, 3d. ed. (Cambridge: Harvard Univ. Pr., 1982), p.136; 19.

27. Ibid., p. $20 ; 35 ; 31$.

28. Michael D. Cohen and James G. March, Leadership and Ambiguity: The American College President, 2d ed. (Boston: Harvard Business Sch. Pr., 1986), p.2; xiv; 123.

29. Frederick E. Balderston, Managing Today's University (San Francisco: Jossey-Bass, 1974), p.43; 46.

30. Derek Bok, "Academe Must Be Wary of Hazards without and Within," The Chronicle of Higher Education, Sept. 17, 1986, p.88.

31. Kerr, Uses, 3d ed. p.156; 177.

32. Balderston, Managing, p.66.

33. Ibid., p.222-23.

34. Battin, "The Library," p.27.

35. Balderston, Managing, p.64. 